\title{
TOEFL Scores of English Department Students Cenderawasih University
}

\author{
Budi Rahayu \\ Universitas Cenderawasih, Papua, Indonesia \\ Email: buray u@yahoo.com
}

\begin{abstract}
This study aims at comparing the TOEFL scores of the English Department students at the Faculty of Teacher Training and Education, Cenderawasih University. The questions that need to be answered are first, whether there are any differences of TOEFL scores amongst English department students from different semesters. Secondly, whether there are any different scores between male and female students, third between the students with different learning background, and forth between students with different levels of interest in English. The participants are the students of semester 2, semester 4, semester 6, and semester 8, commencing in academic year 2017/2018. TOEFL prediction test was given to the participants to get the scores. The scores of each variable were then compared by the application of ANNOVA and t test. The result of this study can give a picture of how English teaching can be improved.
\end{abstract}

Keywords: TOEFL score, comparison, students.

\section{INTRODUCTION}

As the world is changing, Education is also changing and developing. This changing and developing situation of the world should have influenced the teaching and learning program conducted by education institutions. The changing situations are for example the number of students, the background of the students, the ability of the students to achieve the teaching materials, the need of the stakeholders, and others. The way students realize their ideas into texts might also be changing (e.g. Rahayu, 2014). To fulfill those needs, an education institution should always conduct evaluations which can be used to measure the success of the programs and to fulfill the growing needs.

The teaching programs conducted by the department of English teaching, the faculty of Teacher Training and Education, Cenderawasih university have also been exposed to the changing situations as mentioned. As an institution which produce English teachers, this institution should always find innovation to make the students be able to master English, because English is the main knowledge that these candidates of English teachers should certainly master (Rinantanti \& Suhirman, 2018).

To fulfill the changing needs and to search for an innovation in teaching, it is firstly necessary to get accurate data about the existing students. One of the ways to see the students' data is the students' English ability which can be shown by their TOEFL scores. However, data on the TOEFL score of English departments students, Cenderawasih University have not been known. This fact becomes a problem of this 
IJOTL TL, Vol. 5, No. 1, January 2020

p ISSN: 2502 2326; e ISSN: 2502 8278

Https://soloclcs.org; Email: ijolt1@gmail.com

Center of Language and Cultural Studies, Surakarta, Indonesia

Rahayu, Budi. 2020. TOEFL Scores of English Department Students Cenderawasih Universitty. IJOTL TL (2020), 5(1): 51 64. DOI: 10.30957/ijotl -11.v5i1.615.

study. So the research question that need to be answered in this study is: how are the TOEFL scores of the English department students, Cenderawasih University in the academic year of 2017/2018? The next question is whether there are differences of TOEFL score between students of different sex, different learning background, different levels of interest toward English, and different years of commencement.

Being inspired by the research questions above, the purposes of the study in this research are first to describe the TOEFL scores of all English departments students, Cenderawasih University in the academic year of 2017/2018. Secondly, to compare the TOEFL scores of the students of different commencement years. Third, to compare the TOEFL score of the the students with different levels of interest to English. Fourth, to compare the TOEFL scores of the students of different sex, and fifth to compare the TOEFL score of the students from different learning back ground. The result of this research would give accurate data, being useful for adapting and or improving the curriculum, teaching materials and teaching methods as the situations are changing.

\section{LITERATURE REVIEW}

There are several concepts that become a framework and background for this study: Program Evaluation, TOEFL test, and factors influencing the students' academic achievement.

\subsection{Evaluation}

Program evaluation in the teaching of foreign language, especially English teaching, is conducted to measure how far the purpose of the program have been reached. Zainul and Nasution (1992) used the term 'assessment' for evaluation. According to them, assessment is defined as a process to make a decision by using information found by measuring the result of learning either using a test or non-test. This definition suggests that the result of an assessment is used for the following decision making.

Evaluation according to Arikunto (2006) includes measurement and assessment. He gives an example of an orange. Someone buys an orange by firstly measure the size, the taste, etc. With the result of the measurement then the orange is assessed whether it is worthwhile bought. Arikunto then explains 4 functions of assessment. They are for selection (e.g selection for school entrance), as diagnosis (to know the weaknesses of someone on certain thing), for placement (for placing a student to a group who have similar ability), and as the measurement of success (to know how successful a program is reached). Relevant to Arikunto's statement, this research is aimed at measuring the success of English teaching at the English department, Cenderawasih University.

Another says that in an evaluation, there is an assessment. Zainul and Nasution (1994) define measurement by giving numbers to someone with a clear criteria. While Nunan (1992) states that measurement and assessment are identical. The result of the evaluation is then used to decide the following action in order for improvement. Nunan then gives a manual on some aspects which need to be focused in program evaluation. The following are the basic aspects which should be in a program evaluation. 
IJOTL TL, Vol. 5, No. 1, January 2020

p ISSN: 2502 2326; e ISSN: 2502 8278

Https://soloclcs.org; Email: ijolt1@gmail.com

Center of Language and Cultural Studies, Surakarta, Indonesia

Rahayu, Budi. 2020. TOEFL Scores of English Department Students Cenderawasih Universitty. IJOTL TL (2020), 5(1): 51 64. DOI: 10.30957/ijot1 tl.v5i1.615.

\begin{tabular}{|l|l|}
\hline Focus in Evaluation & Examples of the questions \\
\hline Planning process & \\
\hline Needs analysis & $\begin{array}{l}\text { Is the needs analysis procedure effective? } \\
\text { Is the needs analysis informative for the program planning? } \\
\text { Does this needs analysis give data which is useful for the } \\
\text { objective and subjective importance? }\end{array}$ \\
\hline Content & $\begin{array}{l}\text { Does the purpose come from needs analysis? } \\
\text { If not, where does it come from? } \\
\text { Is the purpose appropriate for the intended learners? } \\
\text { Do the learners think that the content is appropriate? } \\
\text { Is the content appropriately stratified ? } \\
\text { Does the content considers the obstacles in the process of } \\
\text { speaking? }\end{array}$ \\
\hline Implementation & $\begin{array}{l}\text { Are the materials, method and activities appropriate with the } \\
\text { purpose? } \\
\text { Do the leaeners think that the materials, methods and the activities } \\
\text { are appropriate? }\end{array}$ \\
\hline Methodology & Are the sources adequate? \\
\hline Source & $\begin{array}{l}\text { Is the teachers' managerial skill adequate? } \\
\text { Are the students' learning strategy efficient? } \\
\text { Does the students come to class regularly? } \\
\text { Do the students give full attention in the class? } \\
\text { Do the students practice outside the class room? } \\
\text { Do the students lok enjoying the class? } \\
\text { Do the arrangement of time and place appropriate with the } \\
\text { studnts' will? } \\
\text { Do the students have problems interrupting the learning? }\end{array}$ \\
\hline Teachers & $\begin{array}{l}\text { Is the evaluation procedure appropriate with the intended } \\
\text { purpose? } \\
\text { Is there any chance for self evaluation for students? If yes, how? } \\
\text { Is there any chance for the students to evaluate the learning } \\
\text { aspects such as materials, methodology, time and place } \\
\text { allocation? } \\
\text { Is there any self evaluation for for the teachers? }\end{array}$ \\
\hline Measurement and & $\begin{array}{l}\text { Evaluation } \\
\text { Learners }\end{array}$ \\
\hline
\end{tabular}

(Nunan, 1992, p.191)

As shown on the last part of the table, measurement is part of evaluation. Furthermore, Nunan also says that one of the categories of evaluation can be a test. Relevant to Nunan, Bachnan (1990) states that a test is part of the evaluation in a teaching program. In this research, evaluation is conducted by giving TOEFL test to students of English Department, as an indicator of the success of teaching program. The finding of this result can be used for planning the next program, as stated by Arthur Hughes (2008). 
IJOTL TL, Vol. 5, No. 1, January 2020

p ISSN: 2502 2326; e ISSN: 2502 8278

Https://soloclcs.org; Email: ijolt1@gmail.com

Center of Language and Cultural Studies, Surakarta, Indonesia

Rahayu, Budi. 2020. TOEFL Scores of English Department Students Cenderawasih Universitty. IJOTL TL (2020), 5(1): 51 64. DOI: 10.30957/ijot1 tl.v5i1.615.

Another concept of a test is delivered by McNamara (2006, p. 765). According to him, a testis aimed at "gathering information about the test takers from observed performance under test conditions". Relevant to the concept, this research is aimed at finding accurate information about the English ability of the students of English department, Cenderawasih University in the academic year 2017/2018.

Related to a language test in an evaluation, Hughes (2003) and Johnson (2008) explain different kinds of test: 1) Proficiency test, to measure the ability of test takers in a language, 2). Achievement test, a test which measures the success of a language learning, 3). Diagnostic test, a test which function to analyze the strengths and witnesses of language learners, and 4). Placement test, a test which functions to place language learners to an appropriate class based on their abilities. This research can be used for the importance of functions 1, 2, and 3, especially, and for all functions generally. That is, this TOEFL test in this research is intended to be used to measure the students' proficiency in English (proficiency test), is used to measure the success of the program conducted so far (Achievement test), and also used to find the strengths and weaknesses of the students in leaning English (Diagnostic).

\subsection{TOEFL test}

The second topic related to this research is the essence of TOEFL test. Having been popular, TOEFL stands for the Test of English as a Foreign Language. This test is a standardized English test to measure the ability of English of non native speakers of English. (Ang-Zie, 2016). TOEFL is used to test the ability to listen, to read, to understand structure and written expressions. Although there are similarities amongst TOEFL tests published by different publishers, the scoring ways may be different. For example, the highest score for TOEFL test written by Deborah Phillips (1996) is 677, while others can be more that that. Research on the TOEFL scores of Indonesian University students might have been conducted elsewhere, and one was conducted in Malang State University, especially to the students who were commencing in the program of Master and Doctorate degree. In the research, it was found that the average score of the TOEFL of the students was 415.97 (Saukah, 2003). This research can give descriptions for comparison to the TOEFL tests conducted elsewhere in the past.

\subsection{Factors influencing the students' academic achievement}

Many factors can influence the students' academic achievement. The first can be prior knowledge and interest (e.g. Siagian, 2015). Furthermore, motivation is also identified as the prompt for students to study hard and therefore to succeed (Saptono, 2016). Another factor which can influence the students' academic achievement can be the gender (eg. Nisa, 2012).Another researcher, Riyani (2012) found that many factors can influence the success of the students' study, amongst them being the process of learning and teaching, Methods, Resources, Motivation, interaction of the students with the materials. Other researchers also found that prior knowledge, motivation, learning habits, environment, facilities have significant influence to the students' academic achievement (Saputro, Ardiawan, Fitriawan, 2015). 
IJOTL TL, Vol. 5, No. 1, January 2020

p ISSN: 2502 2326; e ISSN: 2502 8278

Https://soloclcs.org; Email: ijolt1@gmail.com

Center of Language and Cultural Studies, Surakarta, Indonesia

Rahayu, Budi. 2020. TOEFL Scores of English Department Students Cenderawasih Universitty. IJOTL TL (2020), 5(1): 51 64. DOI: 10.30957/ijot1 tl.v5i1.615.

There might be many more factors which contribute to the success of students in academic achievement, but in this study the feasible and relevant factors researched are the factors of gender, prior knowledge or learning background, and interest to English.

\section{METHODS}

The method used in this research is a survey. The purpose of survey method is to describe the condition of a population (Frankel \& Wallen, 2006). The condition in this research is the English ability of the English department students which is measured by TOEFL test. The test was given to all students of English department students. From the test, descriptions of all students were given. Then the average score of the following variables were calculated: students of each semester, students with different gender, students with different learning background, and students with different interest to English.

The population of this research is all students of English department, Cenderawasih University registered in academic year 2017/2018, which consist of 120 students. All population were taken as sample. All samples were given a TOEFL test to get data, which are the TOEFL scores. However, some students answering sheets were not included because they were not completed as expected. This data were then analyzed using descriptive statistic. With this analysis, the result of the analysis was displayed in tables and diagrams. Additionally, statistical analysis of inferential was also used. Inferential statistic analysis was used to find a conclusion of one thing (Fraenkel \& Wallen, 2006). In this research, inferential statistic analysis was used to find the differences of TOEFL scores amongst students from different commencement years, differences between students from learning background, differences between different sex, and differences between different levels of interest to English. The procedure of the research can be summarized in the following diagram:

\section{Data collection}

Giving TOEF test to all students of English Department

\begin{tabular}{|c|}
\multicolumn{1}{|c|}{ Data analysis } \\
Descriptive statistic: describing TOEFL score of all students and \\
students group of each commencement year. \\
Inferential statistic: Comparing TOEFL scores of students from \\
different commencement years, from different sex, from different \\
learning background, from different interest to English. \\
\hline
\end{tabular}

\section{Interpretation}

Finding reasons and predicting effects of the fact in the finding. 


\section{FINDING AND DISCUSSION}

Finding and discussion are explained in four sections: TOEFL score of students with different sex, TOEFL score of students with different learning background, TOEFL score of students with different interest in English, and TOEFL score of students from different commencement years.

\subsection{TOEFL score of students from different sex}

The analysis shows that based on the gender, the TOEFL score does not show significant difference. The result of t test gives an obtained value of 0.085 , higher than significance value of 0.05. This indicates that gender does not have effect to the English ability of the students of English department, Cenderawasih University. This is different from what Mulac, Wiemann, Widenmann, and Gibson (2009) state that gender can affect the ability of the language. The reason for this result might be because in TOEFL test, the materials are emphasized on skills (listening, reading, structure), not content knowledge. It is obvious that both male and female students have to master the language skills regardless of their interest on the topic.

The implication of being no difference of TOEFL score between male and female students is that gender does not need to be considered in the decision making in regard to the method of English teaching.

\subsection{TOEFL score of students with different learning background}

Learning background can mean 2 things. Firstly, it is the major of the study and secondly, it is the extra time allocated by the students to study English outside the classroom.

Learning background is the major of study when the students were studying in their senior high school. They are IPA class (science), IPS class (Social science) and Bahasa class (Language arts). In this research, 52 students come from Science class, 26 come from social science class, and 10 students come from Language arts class.

To find the differences of the students' scores with 3 learning backgrounds (IPA, IPS, Bahasa), the test of ANOVA was applied. The result of the test shows that the obtained value is 0.508 , higher that the significant value of 0.05 . This suggests that there is not any significant differences of the TOEFL score amongst students from different learning background. 
IJOTL TL, Vol. 5, No. 1, January 2020

p ISSN: 2502 2326; e ISSN: 2502 8278

Https://soloclcs.org; Email: ijolt1@gmail.com

Center of Language and Cultural Studies, Surakarta, Indonesia

Rahayu, Budi. 2020. TOEFL Scores of English Department Students Cenderawasih Universitty. IJOTL TL (2020), 5(1): 51 64. DOI: 10.30957/ijot1 tl.v5i1.615.

The insignificant difference of TOEFL scores amongst students with different background learning indicates that the learning of English in senior high schools in the three classes are similar. In other words, the English department students coming from Language major should have had higher TOEFL score compared with the students coming from IPA and IPS majors. The logical explanation of why the students with Language major background do not have higher score of TOEFL compared with those with other learning backgrounds is that according to the teachers, the students going to Language Arts are usually those who are not eligible to go to IPA or IPS classes. In other word, English department students coming from IPA and IPS already have competent academic proficiency, leading to their ability to learn English well, as well as those coming from Language major. As proved before, prior knowledge can have significant influence on the academic success (Adjani \& Adam, 2012; Saputro, Ardiawan \& Fitriawan, 2015).

The above condition indicates the need for improving the system in English language teaching in senior high schools, in order for the students who major in Language class really have higher competencies in English compared with the students with other majors. The improvement of the system can include curriculum, the method of placement in the major classes, as well as the teaching methods.

The second learning background in this research is whether the students have ever taken additional English courses, either before or after commencing to English department, Cenderawasih University. The data shows that 35 students took the additional English courses, 34 students did not, and 9 students did not respond.

To find the difference of the TOEFL scores between the two groups (those with additional English courses and those without), $t$ test was applied. The obtained value of the test is 0.198 , while the significance value of $t$ is 0.05 . This $t$ test indicates that there is not any significant difference between the TOEFL score of the two groups.,i.e between the students attending additional English courses and those not attending additional English courses.

The TOEFL scores which are not significantly different between these two groups may suggest several possibilities. The first possibility might be the process of teaching English in the department of English language Education which cannot facilitate the more talented students to develop further. This can be caused by some limited facilities which should be able to support self-study activities such as libraries, language laboratory, self-access materials, and so on. As proved by Saputro, Ardiawan, and Fitriawan (2015) that facilities become one of the important factors for students to be successful.

The second possibility is that those who had attended additional English courses might not have more competence, which could have been caused by incompleteness of the additional courses or learning habits (Saputro, Ardiawan, and Fitriawan, 2015)

Being exposed to the mentioned condition, it is necessary to facilitate the English department with equipments which can support all students to develop, especially those who have more potential. The facilities needed can be self-access materials, in order for the students to study themselves to develop their potentials based 
IJOTL TL, Vol. 5, No. 1, January 2020

p ISSN: 2502 2326; e ISSN: 2502 8278

Https://soloclcs.org; Email: ijolt1@gmail.com

Center of Language and Cultural Studies, Surakarta, Indonesia

Rahayu, Budi. 2020. TOEFL Scores of English Department Students Cenderawasih Universitty. IJOTL TL (2020), 5(1): 51 64. DOI: 10.30957/ijot1 tl.v5i1.615.

on their levels, which consist of listening materials, reading materials and other books on English language.

\subsection{TOEFL score based on the students' interest in English}

In this research, interest in English is shown by their choice of study when they registered to the university. If English department is their first choice of study, it is evidence that they have high interest in English. On the contrary, if English is not their first choice of study, it is evidence that their interest to English is low. The data show that 66 students choose English as their first choice of study and 19 students choose English not as their first choice, and 3 students did not respond.

The t-test was applied to find the difference of the TOEFL score between the students who choose English as their first choice and those who choose English not as their first choice. The t test results in the $t$ obtained of 0.54 , far from the significance value of 0.05 . In other word, there is not any significant difference of TOEFL score between the students with English as the first choice and those with English not as the first choice. This result has raised a question since much research found that interest or motivation has very important role in supporting the success of the study (e.g: Munawaroh, 2011). There might be several causes of this contradicted finding. The first possibility is that the students with low interest in English had already had good academic record, so when they were studying in the English department, they could follow the learning processes well. The second possibility is that the teaching processes in the English department cannot support to maximize the potentials of the students with high interest in English. Therefore, there needs to be attempts to maximize the students' potentials through various ways such as self access materials.

\subsection{TOEFL scores based on commencement year of the students}

The students participating in this research are the students commencing in the years of 2013, 2014, 2015, and 2016. The average score of the TOEFL of each group can be seen in Table 1 .

Table 1 suggests that the students commencing in 2014 have the highest TOEFL score (423.33), then the students commencing in 2013 is the second with 403,56, students commencing in 2015 is the third with 401.88, and the last is the students commencing in 2016 with 386.79 .

Table 1: TOEFL score based on the students' commencement year

\begin{tabular}{|c|c|}
\hline Commencement year & TOEFL average score \\
\hline 2013 & 403.56 \\
\hline 2014 & 423.33 \\
\hline 2015 & 401.88 \\
\hline 2016 & 386.79 \\
\hline Total rata-rata & 403.89 \\
\hline
\end{tabular}


IJOTL TL, Vol. 5, No. 1, January 2020

p ISSN: 2502 2326; e ISSN: 2502 8278

Https://soloclcs.org; Email: ijolt1@gmail.com

Center of Language and Cultural Studies, Surakarta, Indonesia

Rahayu, Budi. 2020. TOEFL Scores of English Department Students Cenderawasih Universitty. IJOTL TL (2020), 5(1): 51 64. DOI: 10.30957/ijot1 tl.v5i1.615.

As listed in the table, an interesting thing is that the students commencing in 2014 have higher score than their seniors, commencing in 2013. Whether the difference is significant can be explained in the later discussion. Regardless of the significance, evidence shows that the score of students commencing in 2014 is higher than those commencing in 2013. This evidence declines the expectation that more senior students have higher score in TOEFL. This fact might have been caused by several factors. The first factor might be the prior ability of the students when they registered to the English department. the prior ability of the students commencing in 2014 which could have been higher compared with students of 2013 when they registered. Second factor might be the time for studying when the TOEFL was administered. When this TOEFL was administered, the students of 2014 was taking TOEFL preparation class. So they know the tricks of TOEFL test. This relevant to what Saputra, Ardiawan and Fitriawan (2015) found that learning habits can influence the academic achievement. While the students of 2013 had taken the TOEFL preparation class 1 year before and they might have forgotten. This finding can suggest that TOEFL preparation class has an important role in improving the students' TOEFL score. Therefore, it is suggested that the students of English department would be better to take TOEFL preparation course, regardless of the institutions conducting the course, before they graduate.

\subsection{The difference of TOEFL scores amongst students of different commencement years}

To find the difference of TOEFL score of the students from different commencement years, ANOVA was applied. The first step was to examine the normality of the distribution of the data. Normality test of SPSS shows that the distribution is normal, as listed on Table 2 .

Tabel 2: Normality test

\begin{tabular}{|l|l|c|c|}
\hline \multicolumn{2}{|l|}{ One-Sample Kolmogorov-Smirnov Test } \\
\hline \multicolumn{2}{|l|}{} & Score & commencement \\
\hline \multirow{2}{*}{ Normal Parameters ${ }^{\text {a }}$} & Mean & 88 & 88 \\
\cline { 2 - 4 } & Std. Deviation & 4.01672 & 2.7273 \\
\hline Most Extreme Differences & Absolute & 5.258331 & 1.09047 \\
\cline { 2 - 4 } & Positive & .056 & .197 \\
\cline { 2 - 4 } & Negative & .056 & .168 \\
\hline Kolmogorov-Smirnov Z & -.051 & -.197 \\
\hline Asymp. Sig. (2-tailed) & .521 & 1.844 \\
\hline a. Test distribution is Normal. & .949 & .002 \\
\hline
\end{tabular}

As listed in Table 2, the obtained value is 0.002 . Because the obtained value is lower than the significance value $(0.05)$, so this data is categorized as normally distributed. Therefore, it is appropriate to use one way ANOVA to find the difference of the TOEFL scores amongst the students of different commencing years. 
IJOTL TL, Vol. 5, No. 1, January 2020

p ISSN: 2502 2326; e ISSN: 2502 8278

Https://soloclcs.org; Email: ijolt1@gmail.com

Center of Language and Cultural Studies, Surakarta, Indonesia

Rahayu, Budi. 2020. TOEFL Scores of English Department Students Cenderawasih Universitty. IJOTL-TL (2020), 5(1): 51 64. DOI: 10.30957/ijot1 -1l.v5i1.615.

One way ANOVA is used to find the difference of the TOEFL scores amongst students of 4 different commencement years, they are the students of 2013, 2014, 2015 and 2016. The result of ANOVA test in general can be seen in Table 3.

Table 3: The significance difference of all variables.

ANOVA

\begin{tabular}{|l|l|l|l|l|l|}
\hline Score & & & & & \\
\hline & Sum of Squares & Df & Mean Square & F & Sig. \\
\hline Between Groups & 16810.928 & 3 & 5603.643 & 2.104 & .106 \\
Within Groups & 223744.627 & 84 & 2663.627 & & \\
Total & 240555.556 & 87 & & & \\
& & & & & \\
\hline
\end{tabular}

Table 3 shows that in general the obtained value is 0.106 , higher than the significance value of 0.05 . This suggests that in general, there is no significant difference of TOEFL score amongst the students of 2013, 2014, 2015 and 2016.

The lack of significance difference of TOEFL scores amongst the students of different commencing years might be caused by several factors, one of them being the ability of their English when they began to commence in the English department. When they registered in the English department, their English ability might have been similar. Second possibility for the lack of significant difference amongst the students of different years might be the lack of improvement of the English ability amongst the senior students (students of 2013, 2014, and 2015) since their beginning year in the English department until this research was conducted. However, this second possibility still needs to be studied further by finding the students' TOEFL scores when they began to commence in the English department.

As mentioned before, although there is no significant difference of TOEFL scores amongst the students of different commencing years, ANOVA shows that the TOEFL scores of students of 2014 have significant difference compared with the students of 2016, as can be seen in Table 4.

The table shows that the difference of the TOEFL score between the students of 2016 with the students of 2014 is significant at 0.015 , lower than the significant value of 0.05 . In other word, the difference is significant.

The fact is that the TOEFL score of the students 2014 is the highest amongst others, while the score of students 2016 is the lowest. This situation suggest an obviousness: senior students are expected to have higher scores of TOEFL compared with their juniors. Looking at the significant difference of the two groups of students (2014 and 2016), there is a positive expectation that the result of teaching and learning in the English department, Cenderawasih University is progressing as the time is going. However, again, students of all commencing years need to be given TOEFL test every year to see their progress from year to year. 
IJOTL TL, Vol. 5, No. 1, January 2020

p ISSN: 2502 2326; e ISSN: 2502 8278

Https://soloclcs.org; Email: ijolt1@gmail.com

Center of Language and Cultural Studies, Surakarta, Indonesia

Rahayu, Budi. 2020. TOEFL Scores of English Department Students Cenderawasih Universitty. IJOTL TL (2020), 5(1): 51 64. DOI: 10.30957/ijotl tl.v5i1.615.

Table 4: The significance of the difference of TOEFL scores amongst students of different commencing years.

\begin{tabular}{|c|c|c|c|c|c|c|}
\hline \multirow{2}{*}{$\begin{array}{l}\text { (I) } \\
\text { Commenceme } \\
\text { nt year }\end{array}$} & \multirow{2}{*}{$\begin{array}{l}(\mathrm{J}) \\
\text { Commenceme } \\
\text { nt year }\end{array}$} & \multirow{2}{*}{$\begin{array}{c}\text { Mean } \\
\text { Difference (I- } \\
\mathrm{J})\end{array}$} & \multirow[b]{2}{*}{ Std. Error } & \multirow[b]{2}{*}{ Sig. } & \multicolumn{2}{|c|}{$\begin{array}{c}95 \% \text { Confidence } \\
\text { Interval }\end{array}$} \\
\hline & & & & & $\begin{array}{l}\text { Lower } \\
\text { Bound }\end{array}$ & $\begin{array}{l}\text { Upper } \\
\text { Bound }\end{array}$ \\
\hline \multirow[t]{3}{*}{$\begin{array}{l}\text { commencemen } \\
\text { t } 2013\end{array}$} & $\begin{array}{l}\text { Commenceme } \\
\text { nt } 2014\end{array}$ & -26.00000 & 17.28147 & .136 & -60.3661 & 8.3661 \\
\hline & $\begin{array}{l}\text { Commenceme } \\
\text { nt } 2015\end{array}$ & -4.55072 & 17.12848 & .791 & -38.6126 & 29.5111 \\
\hline & $\begin{array}{l}\text { Commenceme } \\
\text { nt } 2016\end{array}$ & 10.54762 & 16.51377 & .525 & -22.2918 & 43.3871 \\
\hline \multirow[t]{3}{*}{$\begin{array}{l}\text { commencemen } \\
\text { t } 2014\end{array}$} & $\begin{array}{l}\text { Commenceme } \\
\text { nt } 2013\end{array}$ & 26.00000 & 17.28147 & .136 & -8.3661 & 60.3661 \\
\hline & $\begin{array}{l}\text { Commenceme } \\
\text { nt } 2015\end{array}$ & 21.44928 & 15.39103 & .167 & -9.1575 & 52.0560 \\
\hline & $\begin{array}{l}\text { Commenceme } \\
\text { nt } 2016\end{array}$ & $36.54762^{*}$ & 14.70386 & .015 & 7.3074 & 65.7879 \\
\hline \multirow[t]{3}{*}{$\begin{array}{l}\text { commencemen } \\
\text { t } 2015\end{array}$} & $\begin{array}{l}\text { commencemen } \\
\text { t } 2013\end{array}$ & 4.55072 & 17.12848 & .791 & -29.5111 & 38.6126 \\
\hline & $\begin{array}{l}\text { commencemen } \\
\text { t } 2014\end{array}$ & -21.44928 & 15.39103 & .167 & -52.0560 & 9.1575 \\
\hline & $\begin{array}{l}\text { commencemen } \\
\text { t } 2016\end{array}$ & 15.09834 & 14.52375 & .302 & -13.7837 & 43.9804 \\
\hline \multirow[t]{3}{*}{$\begin{array}{l}\text { commencemen } \\
\text { t } 2016\end{array}$} & $\begin{array}{l}\text { commencemen } \\
\text { t } 2013\end{array}$ & -10.54762 & 16.51377 & .525 & -43.3871 & 22.2918 \\
\hline & $\begin{array}{l}\text { commencemen } \\
\text { t } 2014\end{array}$ & $-36.54762^{*}$ & 14.70386 & .015 & -65.7879 & -7.3074 \\
\hline & $\begin{array}{l}\text { commencemen } \\
\text { t } 2015\end{array}$ & -15.09834 & 14.52375 & .302 & -43.9804 & 13.7837 \\
\hline
\end{tabular}

*. The mean difference is significant at the 0.05 level.

\section{CONCLUSION}

The finding and discussion show some fact and tendencies. Firstly, the average TOEFL scores of English department students is 403.89, with the highest score being performed by the students of 2014 (score of 423.33) and the lowest score being performed by the students of 2016 (score of 386.79). Secondly, there is no significant difference of TOEFL scores amongst the students of different commencement years, except between the students commencing in 2014 and those commencing in 2016. Thirdly, there is no significant difference of English department students' TOEFL score between the students of different sex, between students with different learning 
IJOTL TL, Vol. 5, No. 1, January 2020

p ISSN: 2502 2326; e ISSN: 2502 8278

Https://soloclcs.org; Email: ijolt1@gmail.com

Center of Language and Cultural Studies, Surakarta, Indonesia

Rahayu, Budi. 2020. TOEFL Scores of English Department Students Cenderawasih Universitty. IJOTL TL (2020), 5(1): 51 64. DOI: 10.30957/ijot1 tl.v5i1.615.

experiences, between students with different levels of interest in English, between students with different commencing years. Fourthly, The English department, Cenderawasih University has not used TOEFL as an indicator for the quality of the graduates, so the success of the teaching program cannot yet be measured with TOEFL.

Being exposed to the fact findings, there are several recommendations which can be proposed to improve the quality the teaching and learning process in the department of English language and Education, Cenderawasih University. Firstly, TOEFL test needs to be administered annually to the English department students so data about the students' English competence is always updated for any purposes. Secondly, the department of English language, Cenderawasih University, needs to be equipped with more facilities to facilitate the students, especially more prospective students to progress optimally. Finally, similar study is suggested to be conducted in English departments of different universities in Indonesia to get more confirmed conclusion and to compare different strategies in running English teaching programs across Indonesia.

\section{REFERENCES}

Ang-Zie, K. (2016). Preparation and Practice Exam TOEFL. Yogyakarta: Genta Group Arikunto. (2006). Dasar-dasar Evaluasi Pendidikan. Jakarta; P.T BumiAksara Bachman, L. (1990). Fundamental Considerations in Language Testing. Oxford: OUP. Fraenkel, J.R, and Wallen, N.E. (2006). How to Design and Evaluate Research in Education (seventh edition). New York: McGraw Hill.

Hughes, A. (2003). Testing for Language Teachers. Cambridge: CUP

Johnson, K. (2008). An Introduction to Foreign Language Learning and Teaching $\left(2^{\text {nd }} e d.\right)$. Edinburg Gate: Pearson Education

Kapoh, R. J. (2010). Beberapa Faktor yang Berpengaruh Dalam Pemerolehan Bahasa. Interlingua, Vol. 4, pp. 87-95.

McNamara, T. (2006). Language Testing. Dalam Alan Davis \& Catherine Elder (eds.). The Handbook of Applied Linguistics (p.763-783). Malden, Oxford, Victoria: Blackwell Publishing.

Munawaroh, M. (2011). Pengaruh Minat dan Motivasi terhadap Prestasi Bahasa Jepang siswa KelasXI Kayu SMK Negeri 2 Adiwerna Tegal (skripsi).

Retrioeved from: https://lib.unnes.ac.id/6669/1/7841.pdf

Nisa, L.C. (2012). Faktor Jenis Kelamin dalam Hasil Belajar Mahasiswa Fakultas Tarbiah IAIN Walisongo Semarang. Retrieved from: admathedu.uad.ac.id

Nunan, D. (1992). Research Methods in Language Learning. Cambridge: CUP

Phillip, D. (1996). Longman Introductory Course for the TOEFL Test. New York: Longman.

Rahayu, B. (2014). Tenor in Indonesian university students' argumentative texts written in English. Frontiers of Language and Teaching, Vol. 5 (1), pp: $15-26$.

Rinantanti, Y. \& Suhirman, L. (2018). Mapping of the Competence of SHS Students in English Subject in Sarmi and Mamberamo Raya Regencies Papua, Indonesia. The Asian EFL Journal. 20(11), 144-161. 
IJOTL TL, Vol. 5, No. 1, January 2020

p ISSN: 2502 2326; e ISSN: 2502 8278

Https://soloclcs.org; Email: ijolt1@gmail.com

Center of Language and Cultural Studies, Surakarta, Indonesia

Rahayu, Budi. 2020. TOEFL Scores of English Department Students Cenderawasih Universitty. IJOTL TL (2020), 5(1): 51 64. DOI: 10.30957/ijot1 tl.v5i1.615.

Riyani, Y. (2012). Faktor-faktor yang mempengaruhi prestasi belajar mahasiswa. Jurnal EKSOS, Vol.8, No. 1, pp.19-25.

Saptono, YJ. (2016). Motivasi dan Keberhasilan Belajar Siswa. Regula Fidei. Vol. 1, No. 1. Pp. 189-212.

Saukah, A. (2003). Pengajaran Bahasa Inggris di Indonesia: Tinjauan terhadap unjuk kerja pembelajar serta upaya peningkatannya. Dalam Pidato pengukuhan guru besar dalam bidang ilmu pendidikan Bahasa Inggris pada fakultas sastra disampaikan pada sidang terbuka senat Universitas Negeri Malang pada tanggal 3 Maret 2003. Malang: UM.

Setiyadi, B. (2006). Metode Penelitian untuk Pengajaran Bahasa Asing, Pendekata Kuantitatif dan Kualitatif. Yogyakarta: Graha Ilmu.

Siagian, R.E.F. (2015). Formatif: Jurnal Pendidikan MIPA, 2 (2), pp. 122 - 131

Zainul \& Nasoetion (1994. Penilaian Hasil Belajar. Jakarta: Universitas Terbuka. 
IJOTL TL, Vol. 5, No. 1, January 2020

p ISSN: 2502 2326; e ISSN: 2502 8278

Https://soloclcs.org; Email: ijolt1@gmail.com

Center of Language and Cultural Studies, Surakarta, Indonesia

Rahayu, Budi. 2020. TOEFL Scores of English Department Students Cenderawasih Universitty.

IJOTL TL (2020), 5(1): 51 64. DOI: 10.30957/ijot1 tl.v5i1.615. 